MARKO PERIŠA, Ph.D. ${ }^{1}$

(Corresponding author)

E-mail: marko.perisa@fpz.hr

GORAN MARKOVIĆ, Ph.D. ${ }^{2}$

E-mail: g.markovic@sf.bg.ac.rs

PETER KOLAROVSZKI, Ph.D. ${ }^{3}$

E-mail: kolarovszki@gs1sk.org

RADOVAN MADLEŇÁK, Ph.D. ${ }^{3}$

E-mail: radovan.madlenak@fpedas.uniza.sk

${ }^{1}$ University of Zagreb

Faculty of Transport and Traffic Sciences

Vukelićeva 4, 10000 Zagreb, Croatia

2 University of Belgrade

Faculty of Transport and Traffic Engineering

Vojvode Stepe 305, 11000 Belgrade, Serbia

3 University of Žilina, Faculty of Operation and Economics

of Transport and Communications

Univerzitná 8215/1, 01026 Žilina, Slovakia
Human - Transport Interaction

Preliminary Communication

Submitted: 4 Aug. 2017

Accepted: 21 Jan. 2019

\title{
PROPOSAL OF A CONCEPTUAL ARCHITECTURE SYSTEM FOR INFORMING THE USER IN THE IOT ENVIRONMENT
}

\begin{abstract}
Design and development of systems for delivering real-time information to people with disabilities and elderly persons need to be based on defined user requirements. For this purpose, the user requirements have been defined in this paper according to the everyday needs of people who use traffic networks and move in closed spaces. The logical presentation of the functionality of the informing system operation and its subsystems includes all the information (data) important for designing a user information delivery system. The paper presents a conceptual architecture system for delivering user informing services related to the environment based on the Internet of Things concept. The aim of the user informing service is an increase in the level of mobility of persons with disabilities and the senior age groups of users. In order to check the operation of the proposed architecture, the informing system operation was monitored on Arduino Uno and Raspberry Pi platforms in laboratory conditions. A simulation confirmed the interdependence of individual data from different subsystems in order to provide real-time information to the system user. The proposed conceptual architecture can contribute to a more efficient approach to the modeling of assistive technologies (with the aim of informing the users) based on dew/fog/cloud technologies in the Internet of Things environment.
\end{abstract}

\section{KEY WORDS}

information management system; smart wristband; data collection; active daily living;

\section{INTRODUCTION}

In the current age of advanced information and telecommunication technologies development, the application of those technologies in overcoming everyday activities in case of persons with disabilities and senior age groups of users has been constantly increasing. Design of a system and user informing services for this purpose is an increasing challenge in the technical and technological sense and in the financial aspect of cost-efficiency. The technical and technological requirements depend on the impairments disabled people or senior age groups of users have and can be divided regarding vision, hearing and speech impairments. In senior persons, the most common problems are various illnesses and problems with mobility, which is usually reflected in the speed of movement. Depending on the individual types of impairments and their characteristics, it is necessary to design the services in order to satisfy all the requirements of the system as well as the users. Services based on advanced information and communication technologies whose purpose is delivering information in order to handle everyday activities can be based on the Internet of Things (IoT) concept. The purpose of such a service is to increase the level of mobility for persons with disabilities and senior groups of users (target user group - TUG).

In this research, based on the analysis of users' needs, user requirements will be defined, according to which the functional elements of conceptual system architecture for delivering informing services will be designed. The study of user needs will take two aspects into account: moving in open and in closed spaces with the aim of providing accurate and real-time information. The information management system (collecting, processing and distributing to the end user) will be based on the cloud computing (CC) technology [1]. The 
environment, depending on the provision of relevant information, will be based on Ambient Assisted Living/ Enhanced Living Environment (AAL/ELE) platform [2]. The objects and the environment in which the user is located can be determined by Bluetooth BLE Beacon technology. The user gets all the relevant information using a suitable application on a mobile device which can identify beacon devices. [3]. All the relevant information that the user receives through the identification of the beacon device can be defined through web environment [4]. The web environment for the target group of users needs to be designed according to the WCAG 2.0 guidelines and auxiliary technologies and use HTML5 technology for adaptability to monitors of different mobile devices $[5,6]$.

In closed spaces, apart from using beacon technology, the users can be informed by means of automatic identification and data capture (AIDC) technology, which includes RFID and NFC technologies [7, 8]. Also, applications and mobile devices are increasingly used in indoor environments for informing users and detecting objects, for example for analysis by an iPhone device and step counting sensor algorithms [9]. Implementation of the IoT concept in order to provide more efficient information to current users is more representative. Some studies monitor the development of sensory technology within the concept of loT through the phases of development and planning of a smart city environment [10-12]. These studies analyzed the possibility of applying the loT concept for the purpose of improvement of informing users located in the environment and opportunities that the loT concept provides.

Apart from applicative solutions installed on the user's mobile device, informing the user is also possible by using a smart wristband. The smart wristband is applied mostly in order to inform the user about his/her health condition (pulse, blood pressure) or to remind the person to take his/her medicine) [13-16]. Apart from health purposes, the smart wristband can also be used in smart house concepts where information can be collected from the sensors that are in the wireless sensor network (WSN) [17-20].

\section{DEFINING USER REQUIREMENTS AND FUNCTIONALITY OF AN INFORMING SYSTEM}

For the purpose of defining user requirements, a survey was carried out with a target group of users. The survey was conducted on a sample of 80 users $(\mathrm{M}=80)$ who belonged to the group of people with disabilities, whereas a sample from the group of senior persons was 209 users ( $N=209)$.

\subsection{Analysis of user needs}

The research carried out on persons with disabilities was done in cooperation with the Up2date Center for Research, Education and Applied Knowledge, which included 80 users with various types of impairments. Of the abovementioned number of respondents, the male population involved in the survey was 43 while the surveyed female population was 37 . The types of impairments of the surveyed users are shown in Figure 1.

Assessment of satisfaction with the current method of providing information in a traffic environment was studied in several areas: open space (squares, streets, traffic intersections, public transit stops) and in closed spaces (banks, shopping centers, stations). There were $20 \%$ of respondents who were satisfied with the method of informing about the environment on squares, whereas $80 \%$ were dissatisfied. The dissatisfaction of the respondents is focused on the ways of informing about the environment, because the respondents do not have the opportunity to obtain accurate and real-time information. When it comes to moving along the street and getting information about street names and possible places of collision with others, $78 \%$ of respondents were not satisfied. The method of informing at traffic intersections can be done with audio or tactile design, and $21 \%$ of respondents were satisfied with the accuracy of information, whereas $79 \%$ were not satisfied. Regarding the current method of providing information at public transit stops, $71 \%$ of respondents were not satisfied. In closed spaces such as stations, banks and shopping centers, there

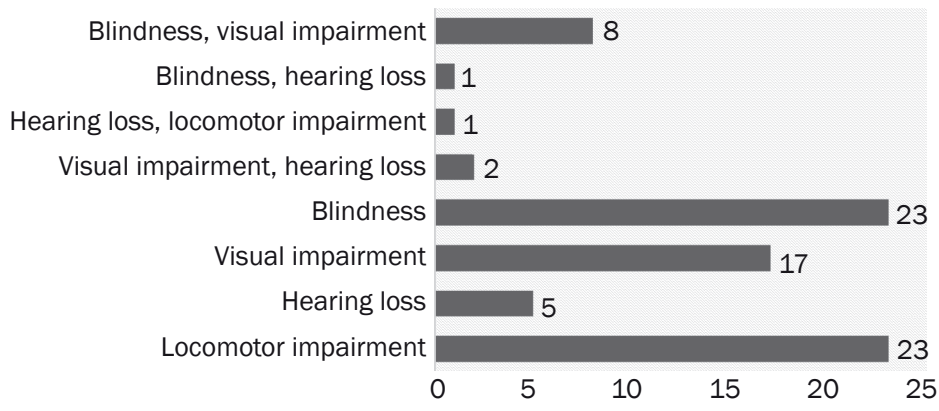

Figure 1 - Types of impairment and presence in respondents 
were $63 \%$ dissatisfied respondents. The information provided to users is not adapted to the degree of user disability, so the dissatisfaction is viewed from this aspect.

The significance of the provided information when moving along the traffic network (open space) has been evaluated in several categories:

- Information about open spaces (squares, gathering places);

- Information about barriers;

- Information about traffic conditions;

- Information about intersection configuration;

- Information about traffic environment (street names, possibilities of redirections);

- Information about public transport (line number, vehicle arrival, vehicle direction, stop configuration), and

- Information about possible problems during movement along the traffic network.

The significance of information while moving through open spaces such as squares and various citizens' gathering places has been evaluated by $67 \%$ of respondents as very important and important (Figure 2). Evaluations of the importance of information are graded 1-5 in the following way: 1 (very unimportant), 2 (unimportant), 3 (neither unimportant nor important), 4 (important), 5 (very important). While moving through a traffic network, the users can encounter various barriers that can threaten their movement safety. The significance of such information is extremely high, expressed by $79 \%$ of respondents (important and very important). The traffic conditions mean possible changes (works, changes in the direction of moving) on the section which the user takes; $85 \%$ of respondents consider this form of information important and very important. When arriving in the vicinity of a traffic intersection, the user needs to be informed about its configuration and elements (number of lanes, existence of a tram, direction of movement, equipment with audio and tactile elements); the importance of the mentioned method was stated by $82 \%$ of respondents.

According to the collected data, $73 \%$ of respondents use smartphone devices while $7 \%$ use feature phones. While performing their everyday activities, the users can encounter various forms of threats to safe movement. The possibility of a fall or change of pulse is one of such forms, where the users can find themselves in a very inconvenient position. In such situations, fast and accurate communication with a certain person or institution is possible and it can be realized through an SOS call or SMS message. Alzheimer's disease can lead to memory disorders or difficulties in carrying out daily activities; for this purpose, the user or their caregiver can be informed about the possible loss of items (wallet, key, etc.). The importance of the form of information about fall or pulse detection is considered important and very important by $56 \%$ of respondents, the information about the movement route by voice guidance and an automatic return route is considered important and very important by $69 \%$ of

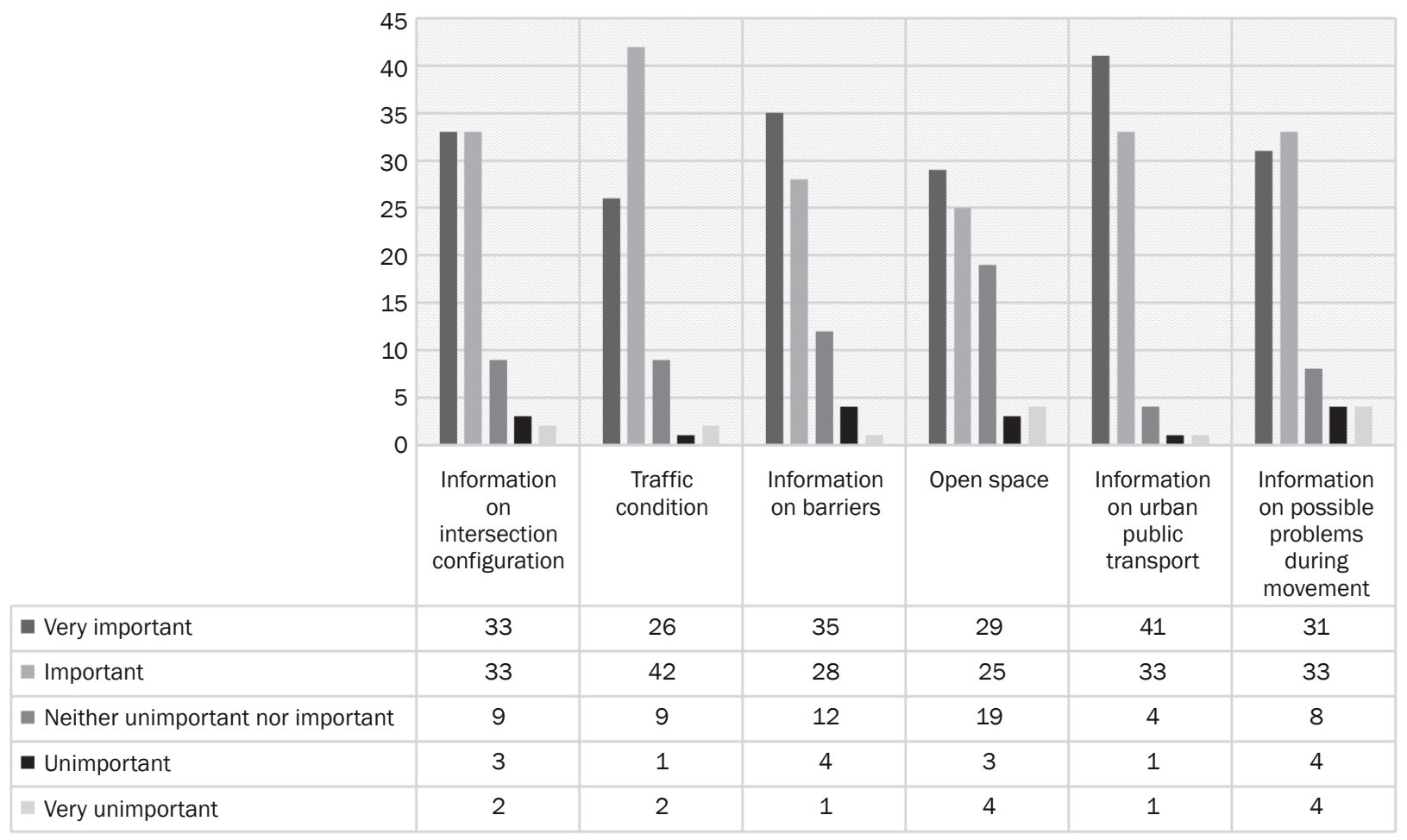

Figure 2 - Assessment of information significance during the users' movement along traffic network 
respondents, the information about locating certain items and a reminder by $62 \%$ and automatic transmission of SOS calls or messages by $61 \%$ (Figure 3 ).

The study of the needs of senior persons has been carried out in nine homes for elderly and helpless people in the city of Zagreb, with 209 respondents interviewed, presenting new possibilities and solutions (smart clock, wristband and the like). Of the 209 surveyed users, 153 were female, and 53 were male users.

The types of impairment present in the elderly users (65+) are shown in Figure 4. The purpose of using mobile devices and services depends on the users're- quirements. Figure 5 shows what are the purposes for which the users would want to use new services, out of which $48 \%$ are orientation and mobility and $24 \%$ are health problems.

The desire to be informed about everyday needs based on the new information and communication technologies and services was expressed by 142 users. According to the data collected, 120 respondents used a feature phone, 55 used a mobile device adapted to elderly people and 34 used smartphones.

The users selected a smart wristband as the method by which they wanted to be informed, as shown in Figure 6 (74\%).

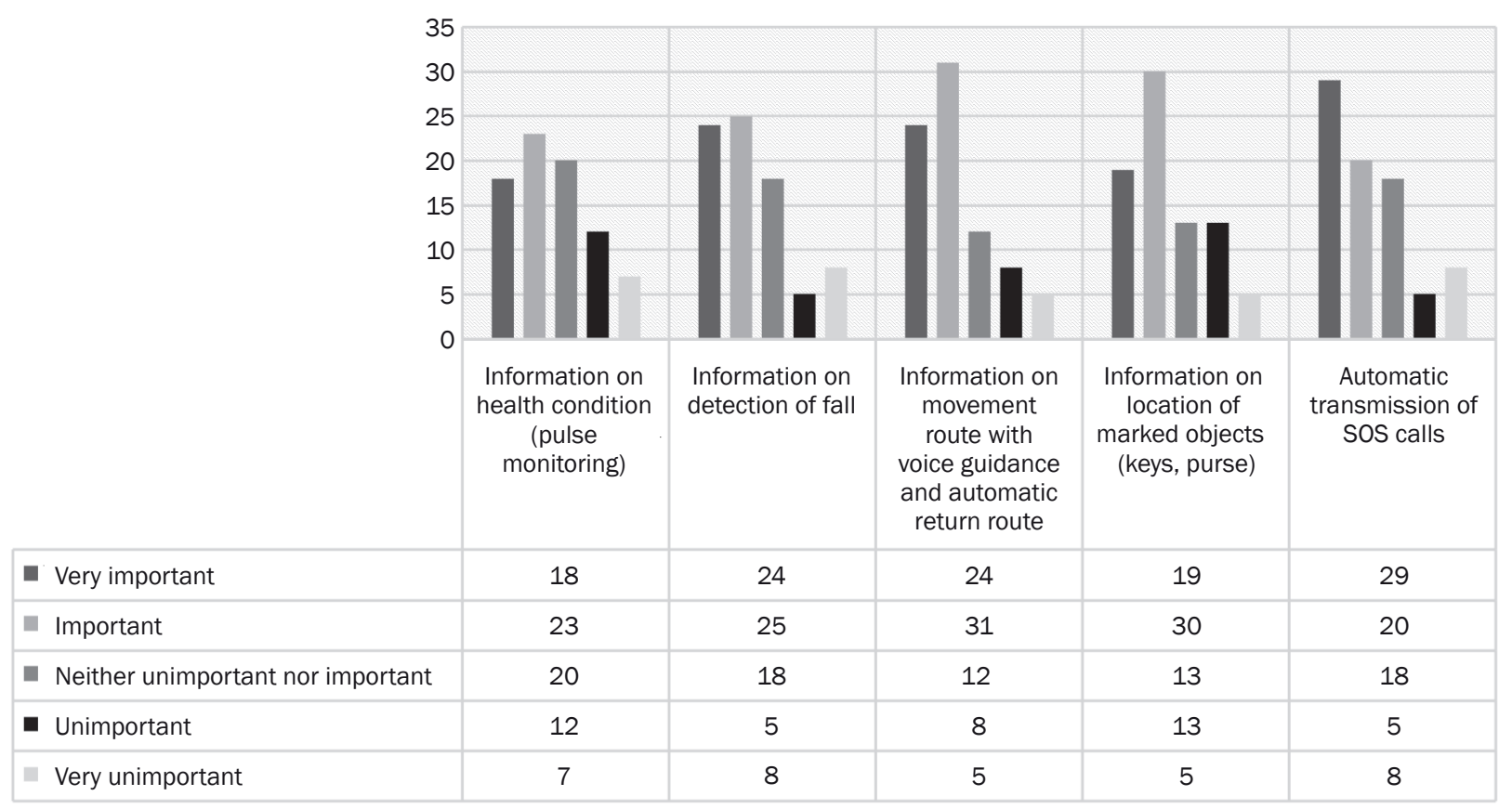

Figure 3 - Assessment of significance of additional information during movement

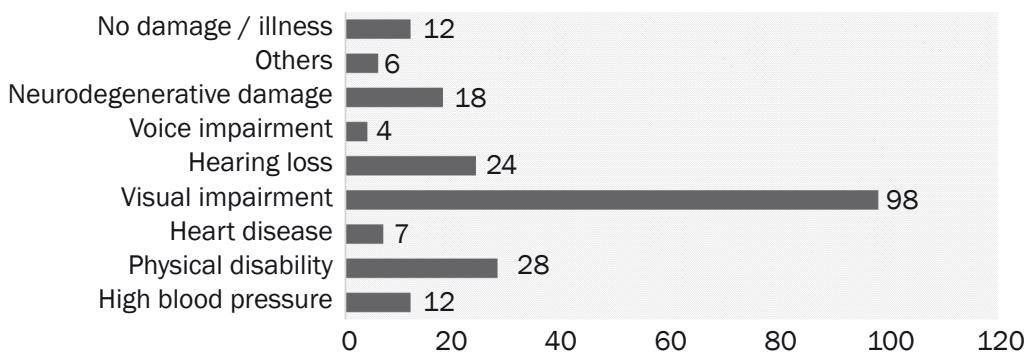

Figure 4 - Types of impairments based on the number of senior users with those impairments

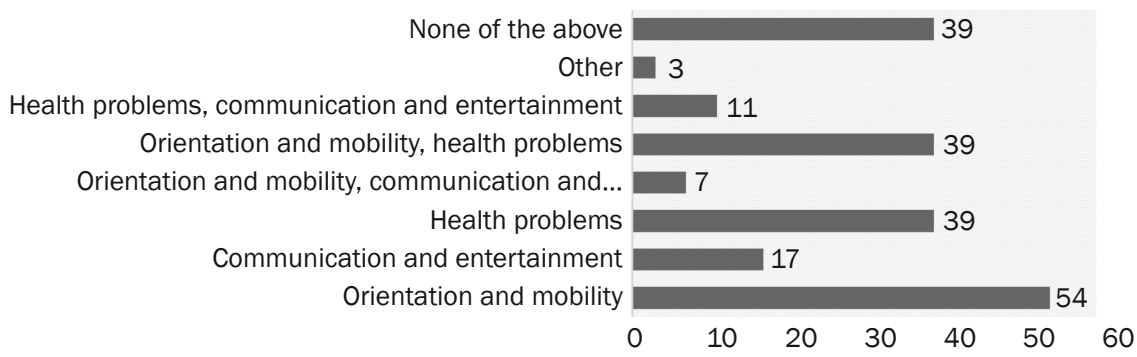

Figure 5 - Purposes of using new services for senior users 


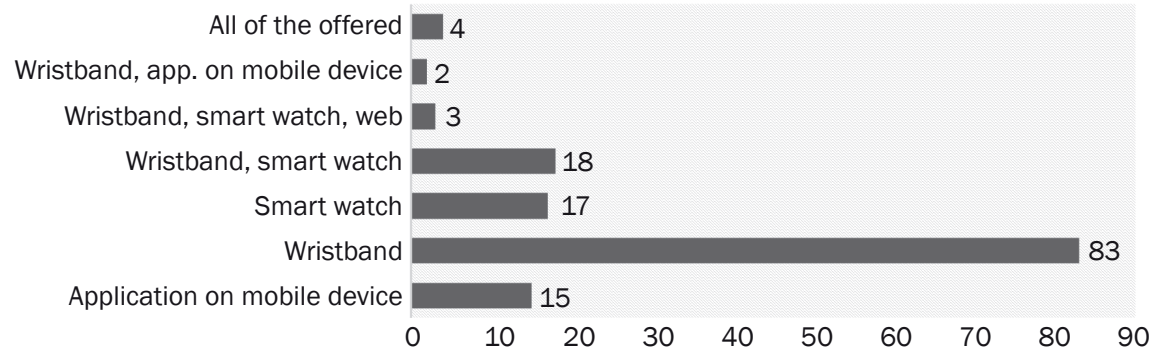

Figure 6 - Possible forms of smart user informing solutions

The performed research (on all relevant facts necessary for informing about everyday needs) has defined the users' requirements as the basis for designing the functionality of the informing service and the requirements of a system design conceptual model for delivering customer information services to the users. User requirements include: navigation, location, environment information, public transport information, fall detection, pulse detection, reminder, object detection and additional requests (SOS calls, additional information, and detection of a violent removal of a smart wristband).

\subsection{Defining the information system functionalities}

Based on the gathered information, the users' requirements have been defined, according to which the functionalities of the system and information services are defined. The proposed functionalities serve to contribute to a better quality of users' information services. The functionalities are presented by the use case diagram (Figure 7) showing the interaction of the users with single subsystems and stakeholders.

The fundamental functionalities of the user information system $\left(S_{\text {inf }}\right)$ are divided into subsystems for: traffic information - $S_{t i}$ (guidance and navigation of users, current location, information on the environment, information on the urban public transport system), information on health - $S_{h i}$ (detection of fall, detection of pulse, reminder for medicines, detection of items) and additional functionalities $S_{a f}$ (SOS help system, detection of violent removal, NFC information, watch, fitness options, information in closed premises).

Table 1 shows a range of functional specifications of the informing system based on user requirements. The range of functional specifications represents the types of information available to be collected from the

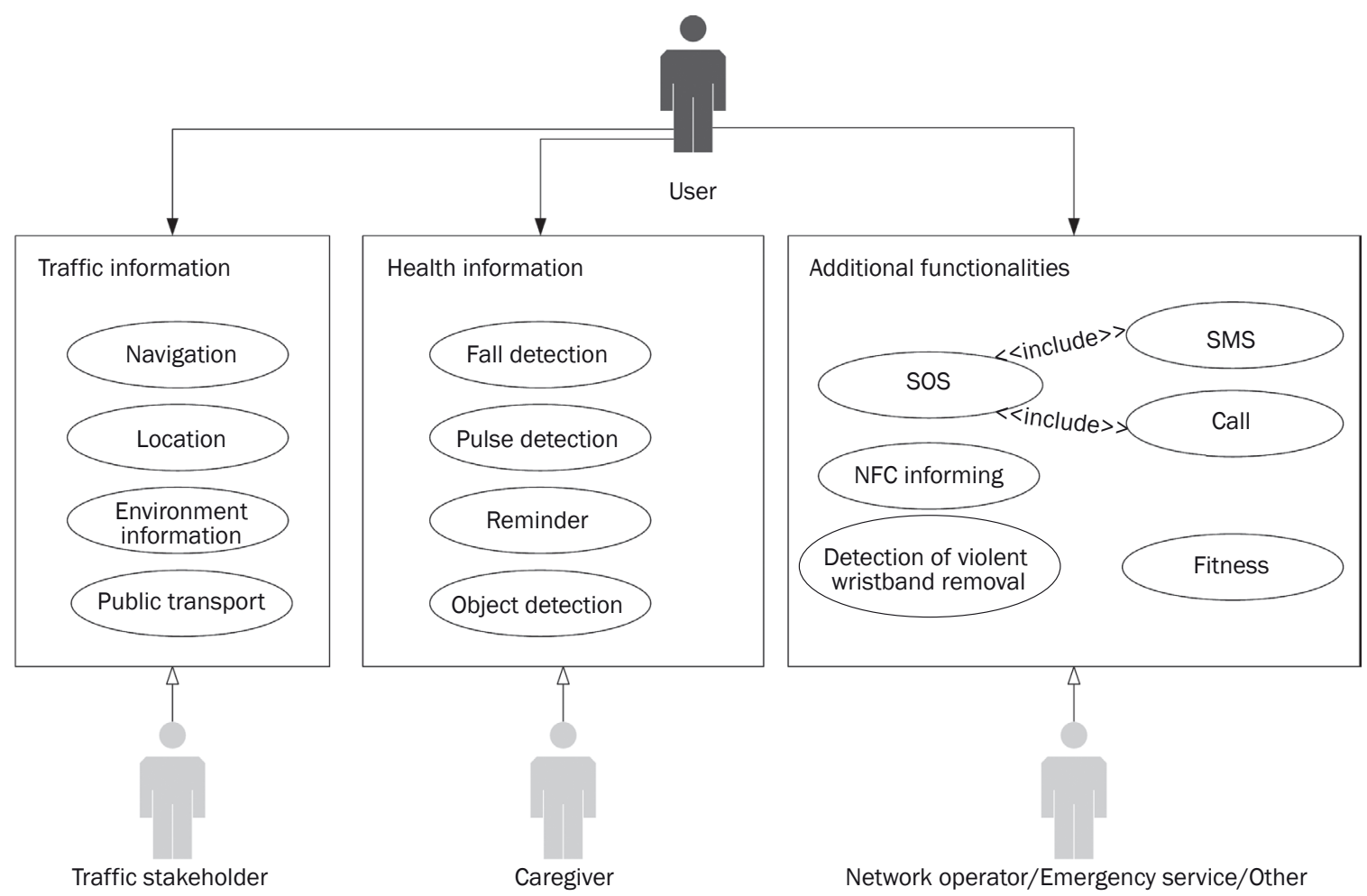

Figure 7 - Functionalities of the information system 
Periša M, Marković G, Kolarovszki P, Madleňák R. Proposal of a Conceptual Architecture System for Informing the User in the loT...

Table 1 - The range of functional specifications needed to meet users' requirements and their labels

\begin{tabular}{||l|c|l|c||}
\hline \multicolumn{1}{|c|}{ Functional specification range } & $\begin{array}{c}\text { Classification of } \\
\text { subsystems }\end{array}$ & \multicolumn{1}{c|}{$\begin{array}{c}\text { Environment } \\
\text { specifications }\end{array}$} \\
\hline \hline Navigation and guidance of users & $S_{t i}$ & Outside & $S_{n a v}$ \\
\hline Location & $S_{t i}, S_{h i}, S_{a f}$ & Outside and inside & $S_{l o c}$ \\
\hline Information on environment & $S_{t i}$ & Outside and inside & $S_{e n v}$ \\
\hline Information in urban public transport & $S_{t i}$ & Outside & $S_{f d}$ \\
\hline Detection of fall & $S_{h i}$ & Outside and inside & $S_{p d}$ \\
\hline Detection of pulse & $S_{h i}$ & Outside and inside & $S_{r e m}$ \\
\hline Reminder (medicines, tasks) & $S_{h i}$ & Outside and inside & $S_{o b}$ \\
\hline Information on objects & $S_{t i}, S_{h i}$ & Inside & $S_{s o s}$ \\
\hline SOS (call and messages) & $S_{a j} S_{h i}$ & Outside and inside & $S_{n f c}$ \\
\hline NFC information & $S_{t i}, S_{a f}$ & Outside and inside & $S_{v i o}$ \\
\hline Detection of violent removal & $S_{a f}$ & Outside and inside & $S_{f i t}$ \\
\hline Fitness & $S_{a f}$ & Outside and inside & \\
\hline
\end{tabular}

environment. There is also an environment where it is possible to use certain information and the subsystem it uses.

The logical presentation of the informing system functionality and its subsystems:

- $S_{i n f}=S_{t i} \cup S_{h i} \cup S_{a f}$ or if there is an expansion with additional subsystems $S_{\text {inf }}=\bigcup_{i=1}^{S} S_{i}$ out of which:

- $\quad S_{t i}=\left\{S_{n a v}, S_{l o c}, S_{e n v}, S_{p t}, S_{o b}, S_{n f c}^{i=1}\right\}$

- $S_{h i}=\left\{S_{f d}, S_{p d}, S_{r e m}, S_{o b}, S_{l o c}, S_{s o s}\right\}$

- $\quad S_{a f}=\left\{S_{s o s}, S_{n f c}, S_{\text {vio }}, S_{f i t}, S_{t o c}\right\}$

Representation of individual elements in defined logical sets:

- $S_{t i} \cap S_{h i} \cap S_{a f}=\left\{S_{l o c}\right\}$

- $S_{t i} \cap S_{h i}=\left\{S_{o b}\right\}$

- $S_{h i} \cap S_{a f}=\left\{S_{\text {sos }}\right\}$

- $S_{t i} \cap S_{a f}=\left\{S_{n f c}\right\}$

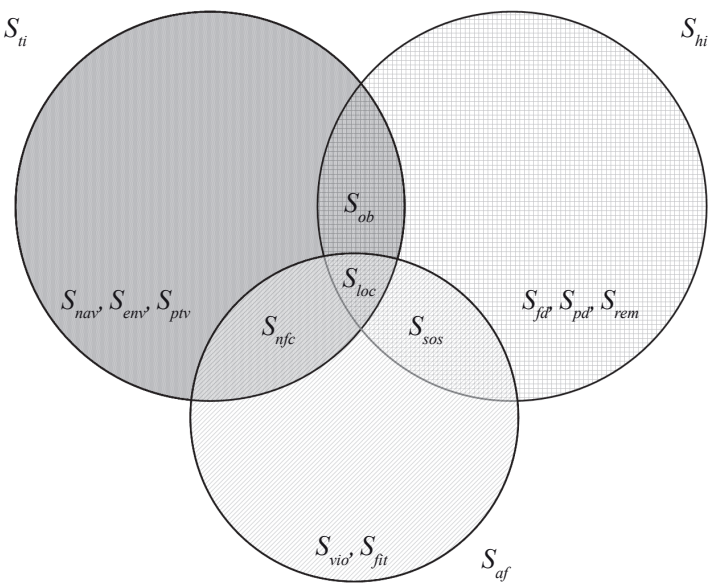

Figure 8 - Presence of information in the defined subsystems
The graphical representation in Figure 8 shows the inclusion of information from all three subsystems (logical connectivity of information and subsystems). Location $\left(S_{l o c}\right)$ is connected with all three subsystems since the delivery of information on the detection of fall, violent removal and SOS calls is necessary to determine the user's location. NFC informing $\left(S_{n f c}\right)$ can be used as additional functionality for the possibility of informing the user in closed spaces about various objects (e.g. shop opening hours or persons in the room) and in urban public transport as the possibility of informing when onboard vehicles. The SOS option $\left(S_{\text {sos }}\right)$ allows a person with a certain problem to inform someone about it. The mentioned option has the possibility of operating as an SMS message (call) and can also operate in the health information subsystem $\left(S_{h i}\right)$. Information on objects $\left(S_{o b}\right)$ can be useful when moving along the traffic network for being informed about objects. All the defined information represents a set of users' requirements.

\section{PROPOSAL OF THE CONCEPTUAL ARCHITECTURE SYSTEM FOR INFORMING USERS}

Based on the defined user requirements and the logical connection of information with subsystems, it is possible to define system requirements for delivering user information service. The information is provided to the end user in the form of a smart wristband. With the proposed conceptual architecture of the system, the aim is to enable the collection of data from the environment and deliver the ultimate information to the user. 
The conceptual system architecture necessary for the delivery of the informing service according to the defined user requirements is based on the IoT concept. In order to process and save the data one can use the CCfB concept and AAL/ELE platform [2, 21].

The aim of the system is to enable gathering and processing of data from the environment (open and closed spaces) and provision of real-time information to the end user; the architecture of such a system can be based on fog technology and the CC concept (Figure 9). Gathering of information from the environment takes place via a sensor on a smart wristband (sensor edge). The information is transmitted via a mobile application (dew class) to a suitable fog node which depends on the type of information or subsystem in charge of its delivery (traffic information, information about health and additional information). The fog node can be found on a private or public CC service using client/server and peer-to-peer technology. The user's terminal device is connected to the fog node via radio access network (RAN). The fog node makes a connection to $\mathrm{CC}$ in the morning and evening hours due to possible latency in real-time demand for the requested information. The interaction among all levels (dew/fog/CC) depends on service-level agreement (SLA) which must satisfy the respective level of service.

All stakeholders can access the information in $\mathrm{CC}$, thus having their level of management defined according to the PaaS model, which allows data management. Every datum is thereafter adjusted by M2M communication into an acceptable form depending on the user's level of impairment. The database stores all data from the sensors located in the smart wristband. It contains data that also require additional processing and are adapted into information understandable to the end user (by means of $\mathrm{M} 2 \mathrm{H}$ communication). The user database, which contains data on user accounts and their settings, is located in a part of the service provider's CC architecture. The user database provides the necessary data for verification and adaptation of the contents according to user priority. The adaptation of the contents is performed based on user characteristics and functionalities the user has selected.

The user accesses his/her data by means of a mobile application on the mobile device or via a web application using a web browser. The web application is used exclusively for defining the user profile and possible pre-travel creation of a travel route. The stakeholders have access to the $\mathrm{CC}$ database depending on the usage subsystem. Figure 10 shows the information flow from the user's request to the delivery of the system; the usage example refers to the subsystem of traffic information (determining the user location). After the user's request for certain information (via a mobile device), respective sensors on the smart wristband are activated. The sensor collects information from the environment and the verification is done by means of a respective fog node. After the verification and confirmation of the requested information, the user receives all the relevant information via the mobile application. Fog delivers real-time information and enables operation in the IoT environment in a time measured in milliseconds [ms]. There is also the possibility of communicating between two or several fogs, the interval of which lasts from a second to a minute. The information is periodically sent to $\mathrm{CC}$ in a time defined according to the system requirements (e.g. 6:00 a.m. every day). In the CC environment, the collection and fusion of data from Fog $_{1} \ldots \mathrm{Fog}_{n}$ and other stakeholders of the

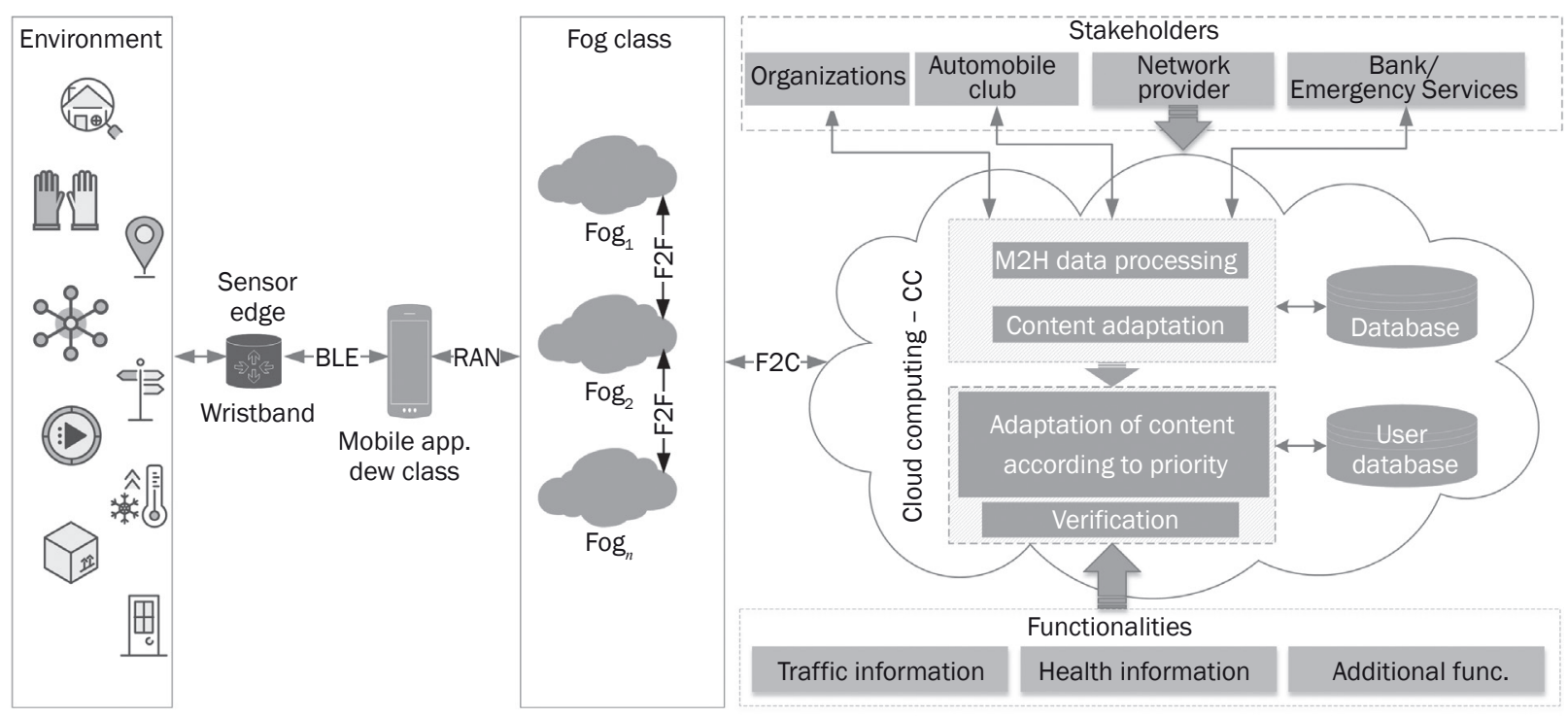

Figure 9 - Proposal of conceptual architecture and functionality of a system based on the loT concept 


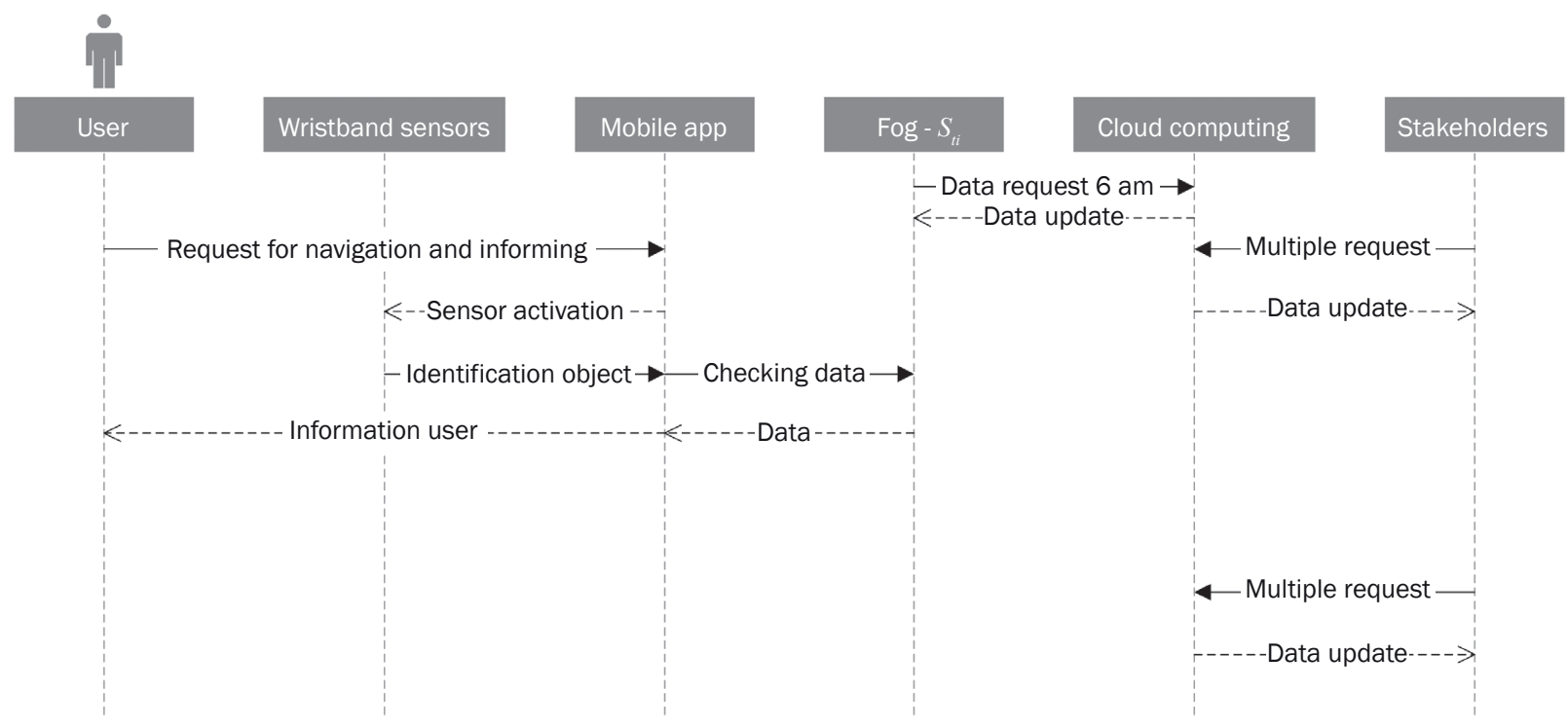

Figure 10 - Information flow from data collection to end information

ecosystem are performed. Based on the processed data, CC delivers the information into the defined subsystems $\left(\right.$ Fog $_{1} \ldots$ Fog $\left._{n}\right)$.

For the presentation of the information flow, the UML sequential diagram is used, and with this presentation it is possible to also show the information flow of the remaining two subsystems or of the possible system expansion.

In the proposed architecture it is also possible to exchange data in Fog2Fog and Fog2Cloud form, thus enabling better operation of the sensors in the loT environment.

\section{PROTOTYPE SOLUTION AND SIMULATION}

In order to simulate the proposed conceptual system architectures for data collection from the environment and end user information, the Arduino Uno development platform, Raspberry $\mathrm{Pi} 3$ and a computer server (CC) were used. The aim of the simulation was to demonstrate the ability for a sensor that contains specific information in an environment of users, their collection and processing in the concept of cloud computing (fog and $\mathrm{CC}$ ) and communication technology to function.

Simulation and operation monitoring were done at the Laboratory for Development and Research of Information and Communication Assistive Technology at the Faculty of Traffic and Transport Sciences.

The Arduino Uno environment was used in the simulation of the smart wristband fitted with the mentioned sensors. GPS module fall detection $S_{f d}$, and 9 axes motion shield were used in order to locate the user, and the NFC module was used for user information $S_{n f c^{*}}$ Communication between single components ran via Bluetooth, LAN and WiFi connections. The user location as data is also important in fall detection, therefore in this case Fog2Fog communication was enabled as data and information exchange from two subsystems.

Each sensor represents one functionality from the defined subsystems. Fog environment is represented by three Raspberry Pi3 micro computers; every microcomputer simulates the operation of one subsystem (fog) equipped with a separate database (Figure 11). Figure 11 shows the recording of data in every defined fog collected from the sensors.

The information is processed in a certain time period and analyzed with CC database. This synchronization is possible in a defined time interval (minutes, days, weeks), whereas the synchronization with fog is expressed in seconds or milliseconds.

Figure 12 shows the detection of location and detection of fall in the respective fog node responsible for the defined subsystem. The performed simulation tested the possibility of detecting certain values from certain subsystems, forwarding and checking information in a written database. This mode of data collection, processing and using $\mathrm{M} 2 \mathrm{H}$ communication to adjust the resulting data into readable information for users (e.g. visually impaired persons) will allow for the creation of personalized information necessary to the user.

\section{DISCUSSION}

While studying user needs, the difficulties of user mobility in a traffic environment have been defined. The proposed conceptual architecture for delivering a user informing service and simulation in laboratory conditions allows the system user to deliver information according to the defined user requirements. $A$ 


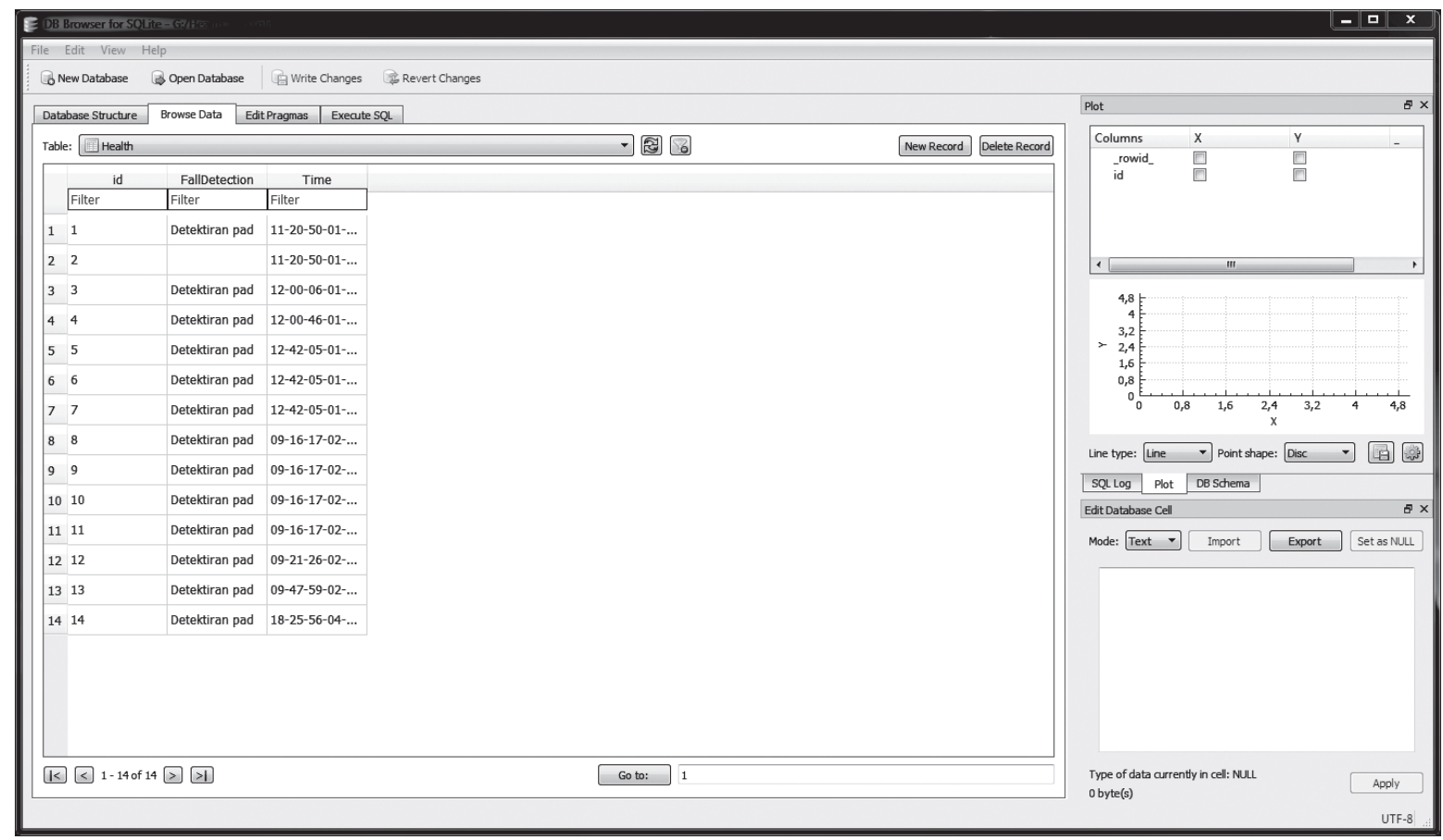

Figure 11 - Fall detection and recording of data into defined fog environments (subsystems)

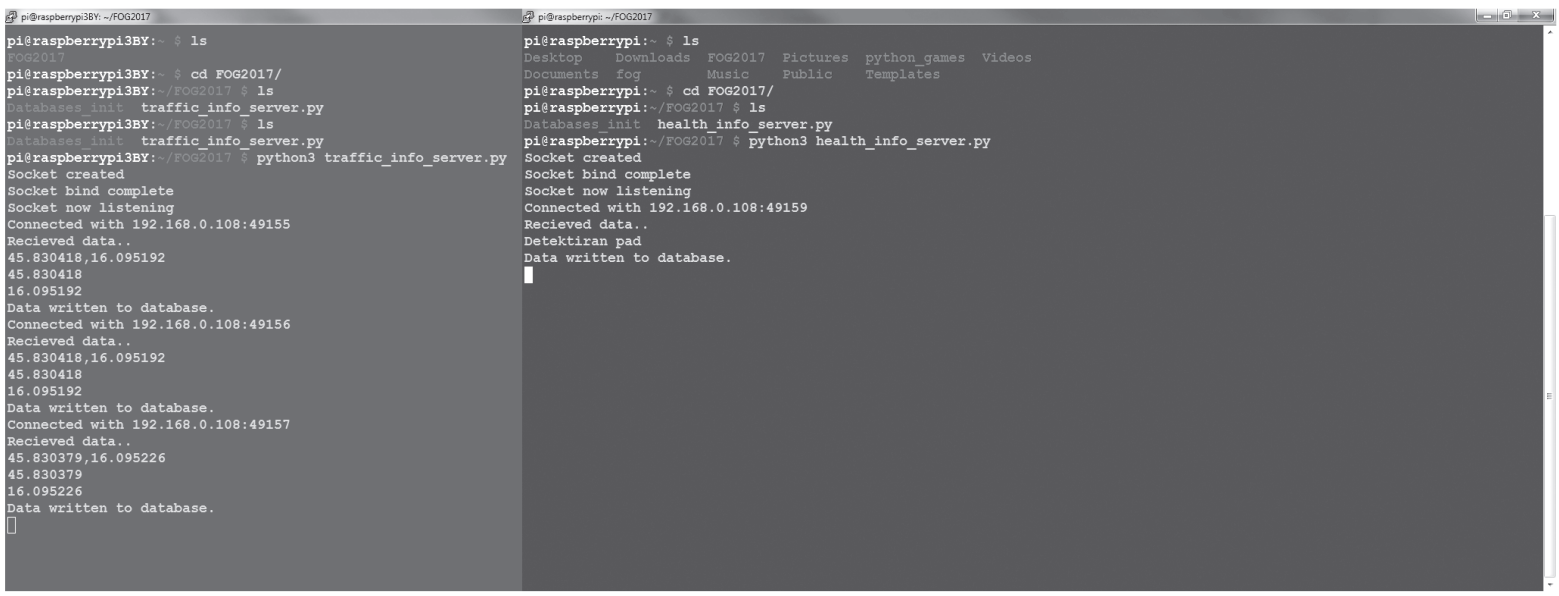

Figure 12 - Detection of GPS location and fall detection

large number of users (79) expressed their wish for the development of the proposed service according to their basic needs, whereas only one user said that he had no wish for the information service. A mobile device and an applicative solution are required for the information provision.

The simulation has proven the method of collecting and processing data through all the elements proposed by the system architecture (dew/fog/CC) and the possibility of creating information towards the end user. The paper also proposes the method of informing the user in the form of a smart wristband which contains all the relevant sensors and the proposed information subsystems. The advantage of such a form of information provision is the simplicity of usage, with $74 \%$ of users selecting a smart wristband. Today's solutions are mainly mobile applications, separate for each functionality, which is an additional load on the concentration of the user.

Through survey and interviewing methods, data about the everyday needs of the users were obtained, which include mobility and provision of information about all relevant elements while moving. According to the obtained results from the survey questionnaires, the environment has been defined, as well as the context of using single data. Estimating the user location is important while data for creating information from the various subsystems is shown and used for testing 
the operation of the proposed architecture. Simulations have demonstrated the possibility of determining the user's location in the proposed conceptual architecture.

Following the development of the IC technology, the advantage of this research compared to the currently available research in the field of user information provision is reflected in the used methodology. This methodology includes the process of defining user requirements and those elements of the conceptual architecture of the system required to provide the relevant information to the end user. The conceptual architecture allows the work to be independent of the degree and type of user disabilities in the form of a modular wristband.

\section{CONCLUSION}

Different groups of users who depend on the level and type of impairment, interests and characteristics also define the functionalities of the proposed services of informing end users. Designing a system that includes defining the working technology, elements of the conceptual system architecture and elements of an applicative solution needs to be directed towards the concepts of universal design and models of assistive technologies. Due to their drawbacks, the currently available solutions on the market do not provide the possibility of equal usage and availability of end information to all groups of users. The simulation has confirmed the interdependence of certain variables of different subsystems with the aim of delivering real-time information to the system user. The proposed logical presentation of the informing system functionality and its subsystems can contribute to a more efficient approach to designing assistive technology systems based on dew/fog/cloud technologies in the Internet of Things concept. Provision of information about the environment, specific user requirements and everyday requirements are important segments when it comes to raising the level of quality of living. In order to achieve this, it is important to include several stakeholders in creating the end information, the information to be adapted to all system users and the availability of a $24 / 7$ service.

\section{Dr. SC. MARKO PERIŠA ${ }^{1}$}

E-mail: marko.perisa@fpz.hr

Dr. Sc. GORAN MARKOVIĆ2

E-mail: g.markovic@sf.bg.ac.rs

Dr. sc. PETER KOLAROVSZKI ${ }^{3}$

E-mail: kolarovszki@gs1sk.org

Dr. sc. RADOVAN MADLEŇÁK ${ }^{3}$

E-mail: radovan.madlenak@fpedas.uniza.sk

${ }^{1}$ Sveučilište u Zagrebu, Fakultet prometnih znanosti

Vukelićeva 4, 10000 Zagreb, Hrvatska

2 Univerzitet u Beogradu, Saobraćajni fakultet
Vojvode Stepe 305, 11000 Beograd, Srbija

3 Žilinská univerzita, Fakulta prevádzky a ekonomiky

dopravy a spojov

Univerzitná 8215/1, 01026 Žilina, Slovensko

\section{PRIJEDLOG KONCEPTUALNE ARHITEKTURE SUSTAVA ZA INFORMIRANJA KORISNIKA U IOT OKRUŽENJU}

\section{SAŽETAK}

Dizajniranje i razvoj sustava za isporuku stvarno-vremenskih informacija osobama s invaliditetom te osobama starije životne dobi potrebno je temeljiti na definiranim korisničkim zahtjevima. U tu svrhu u ovom radu korisnički zahtjevi definirani su prema analizi prikupljenih podataka o svakodnevnim potrebama korisnika koji se kreću prometnim sustavom te zatvorenim prostorom. Korisnički zahtjevi predstavljaju skup informacija prikazanih logičkim modelom podataka važnih za kreiranje funkcionalnosti sustava informiranja korisnika. Analizom dosadašnjih rješenja u području prikupljanja, obrade $i$ isporuke krajnje informacije korisniku predložena je konceptualna arhitektura sustava temeljena na Internet of Things konceptu. Cilj takve usluge jest povećanje stupnja mobilnosti osoba s invaliditetom te starije skupine korisnika. U svrhu provjere rada predložene arhitekture napravljen je monitoring rada sustava informiranja na Arduino Uno i Raspberry Pi platformama u laboratorijskim uvjetima. Testiranjem je potvrđena međusobna ovisnost pojedinih podataka iz različitih podsustava s ciljem kreiranja stvarno-vremenske informacije korisniku sustava. Prikazanim logičkim modelom podataka moguće je doprinijeti efikasnijem pristupu u području modeliranja sustava pomoćnih tehnologija (s ciljem informiranja korisnika) temeljenih na dew/ fog/cloud tehnologijama u Internet of Things okruženju.

\section{KLUUČNE RIJEČI}

sustav upravljanja informacijama; pametna narukvica; prikupljanje podataka; svakodnevne aktivnosti;

\section{REFERENCES}

[1] Abolfazli S, Sanaei Z, Ahmed E, Gani A, Buyya R. Cloudbased augmentation for mobile devices: Motivation, taxonomies, and open challenges. IEEE Commun Surv Tutorials. 2014;16(1): 337-68.

[2] Goleva RI, Garcia NM, Mavromoustakis CX, Dobre C, Mastorakis G, Stainov R, et al. AAL and ELE Platform Architecture. In: Ambient Assisted Living and Enhanced Living Environments. Elsevier; 2017. p. 171-209.

[3] Ahmetovic D, Gleason C, Ruan C, Kitani K, Takagi H, Asakawa C. NavCog. In: Proceedings of the $18^{\text {th }}$ International Conference on Human-Computer Interaction with Mobile Devices and Services - MobileHCl '16. New York. New York, USA: ACM Press; 2016. p. 90-9.

[4] Kibria MG, Chong I. Knowledge-based open Internet of Things service provisioning architecture on beacon-enabled Web of Objects. Int J Distrib Sens Networks. 2016 Sep 27;12(9).

[5] Mulfari D, Celesti A, Villari M, Puliafito A. Providing Assistive Technology Applications as a Service Through Cloud Computing. Assist Technol. 2015;27(1): 44-51.

[6] Abel EE. Overview of Semantic Web Technology: The 
Formulation of Semantic Web Agent System Model to Assist the Blind and Visually Impaired. 2016;6(1).

[7] Wang D, Ge WC, Wang YG. Development of a Health Care Information System for the Elderly at Home. Sung W-P, Kao JCM, editors. MATEC Web Conf. 2016 Mar 8;44: 02011.

[8] Spinsante S, Gambi E. NFC-Based User Interface for Smart Environments. Adv Human-Computer Interact. 2015;2015: 1-12.

[9] Flores GH, Manduchi R. WeAllWalk: An Annotated Data Set of Inertial Sensor Time Series from Blind Walkers. Proc $18^{\text {th }}$ Int ACM SIGACCESS Conf Comput Access ASSETS '16. 2016;141-50.

[10] Domingo MC. An overview of the Internet of Things for people with disabilities. J Netw Comput Appl. 2012;35(2): 584-96.

[11] Ramirez ARG, González-Carrasco I, Jasper GH, Lopez AL, Lopez-Cuadrado JL, García-Crespo A. Towards Human Smart Cities: Internet of Things for sensory impaired individuals. Computing. 2017 Jan 28;99(1): 107-26.

[12] Perakovic D, Perisa M, Cvitic I, Brletic L. Internet of things concept for informing visually impaired persons in indoor environments. In: Proceedings of the $2^{\text {nd }} E A I$ International Conference on Management of Manufacturing Systems. EAl; 2018.

[13] Ghamari M, Soltanpur C, Cabrera S, Romero R, Martinek R, Nazeran H. Design and prototyping of a wristband-type wireless photoplethysmographic device for heart rate variability signal analysis. In: $201638^{\text {th }} \mathrm{An}$ nual International Conference of the IEEE Engineering in Medicine and Biology Society (EMBC). IEEE; 2016. p. 4967-70.
[14] Nelson EC, Verhagen T, Noordzij ML. Health empowerment through activity trackers: An empirical smart wristband study. Comput Human Behav. 2016 Sep;62(September): 364-74.

[15] Wang $\mathrm{C}-\mathrm{H}$, Nien S-H. Combining multiple correspondence analysis with association rule mining to conduct user-driven product design of wearable devices. Comput Stand Interfaces. 2016;45(March): 37-44.

[16] Pramanik PKD, Upadhyaya BK, Pal S, Pal T. Internet of things, smart sensors, and pervasive systems: Enabling connected and pervasive healthcare. In: Healthcare Data Analytics and Management. Elsevier; 2019. p. 1-58.

[17] Augustyniak P, Smoleń M, Mikrut Z, Kańtoch E. Seamless Tracing of Human Behavior Using Complementary Wearable and House-Embedded Sensors. Sensors. 2014 Apr 29;14(5): 7831-56.

[18] Choi H-S, Rhee W-S. IoT-Based User-Driven Service Modeling Environment for a Smart Space Management System. Sensors. 2014 Nov 20;14(11): 22039-64.

[19] Yared R, Abdulrazak B. Ambient Technology to Assist Elderly People in Indoor Risks. Computers. 2016 Oct 10;5(4): 22.

[20] Bauk S, Draskovic M, Schmeink A. Challenges of Tagging Goods in Supply Chains and a Cloud Perspective with Focus on Some Transitional Economies. Promet Traffic \& Transportation. 2017 Feb 16;29(1): 109.

[21] Periša M, Peraković D, Šarić S. Conceptual Model of Providing Traffic Navigation Services to Visually Impaired Persons. Promet - Traffic \& Transportation. 2014 May 26;26(3): 209-18. 